\title{
Wet Oxidation of Fine Soil Contaminated with Petroleum Hydrocarbons: A Way towards a Remediation Cycle
}

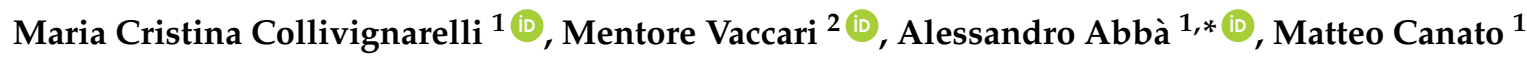 \\ and Sabrina Sorlini ${ }^{2}$ \\ 1 Department of Civil and Architectural Engineering, University of Pavia, via Ferrata 1, 27100 Pavia, Italy; \\ mcristina.collivignarelli@unipv.it (M.C.C.); matteo.canato@unipv.it (M.C.) \\ 2 Department of Civil, Environmental, Architectural Engineering and Mathematics, University of Brescia, \\ via Branze 43, 25123 Brescia, Italy; mentore.vaccari@unibs.it (M.V.); sabrina.sorlini@unibs.it (S.S.) \\ * Correspondence: abba78@unipv.it; Tel.: +39-0382-985-314; Fax: +39-0382-985-589
}

Received: 16 May 2018; Accepted: 6 June 2018; Published: 8 June 2018

\begin{abstract}
The aim of this experimental study was to assess the feasibility of using a wet oxidation (WO) process for treating fine soil with a high level of total petroleum hydrocarbons (TPHs). Two samples of soil were spiked with two different contaminants (motor oil, and motor oil + diesel). The samples were subjected to a WO bench plant test, where the effect of the main process parameters (i.e., temperature and reaction time) on the removal of TPHs was investigated. Results show that the WO process is effective for the decontamination of hydrocarbons, and a strong reduction $(>85 \%)$ can be obtained with the typical working conditions of a full-scale plant (temperature $=250{ }^{\circ} \mathrm{C}$, reaction time $=30 \mathrm{~min}$ ). The solid residue resulting from the WO process was characterized in order to evaluate the recovery options. In terms of chemical characterization, the contents of the pollutants comply with the Italian regulations for commercial and industrial site use. Moreover, the results of the leaching test suggested that these residues could be reused for ceramic and brick manufacturing processes.
\end{abstract}

Keywords: chemical oxidation; contaminated soil remediation; leaching test; recovery options

\section{Introduction}

The rapid and effective removal of total petroleum hydrocarbons (TPHs) from soil can be theoretically obtained through chemical-physical treatments, such as solvent extraction, low temperature thermal desorption, or chemical oxidation. The application of these technologies enables the attainment of high TPHs removal efficiency, even if some drawbacks must be taken into account. For instance, when solvent extraction is applied, the toxicity of the solvent is an important factor, as traces of solvent may remain within the treated soil [1], thereby compromising its quality. On the other hand, for chemical oxidation, reagent costs have to be carefully evaluated during the design phase [2]; for instance, in Fenton's process, high carbonate and bicarbonate concentrations in the soil (as well as the organic matter) can lead to a high dosage of reagents [3], with respect to the stoichiometric amount. Furthermore, the composition of the soil (in terms of granulometry) can also affect the decontamination process; to give an example, soils characterized by a high content of silt and clay cannot be treated effectively with cheaper biological processes, or by soil vapor extraction, because of their low air permeability. Moreover, due to the tendency of the fine fraction of soil to form aggregates, pre-treatments such as shredding could be necessary prior to the decontamination process, increasing the treatment costs. 
In addition, it must be taken into account that due to the tendency of contaminants to accumulate in the fine fraction of soil [4], in many cases, that fraction is not treated, but instead directly landfilled, and the remediation cycle is not completed; something that occurs, as reported by Dermont et al. [5], in soil washing treatment. Another aspect to be taken into account is the change in the partition of the contaminant amongst the different fractions of the soils due to the washing process [6].

In recent times, the European Commission has adopted an ambitious Circular Economy Package [7], aiming to stimulate Europe's transition towards a circular economy. The proposed actions will contribute to "closing the loop" of product life cycles through greater recycling and reuse, and will bring benefits for both the environment and the economy. Therefore, the technicians are motivated to improve or find alternative remediation technologies finalized to close the remediation cycle, and give a new life to waste.

A technology that can be useful in reaching the aforementioned targets is the wet oxidation (WO) process, which is reliable and effective in the treatment of a wide spectrum of organic aqueous waste, even toxic waste, produced by various branches of industrial activity [8,9], and sewage sludge [10].

Typical treatment conditions for sludge and hazardous wastes reported in the literature are as follows: $200-325^{\circ} \mathrm{C}$ for temperature; $5000-17,500 \mathrm{kPa}$ for pressure; and $15-120 \mathrm{~min}$ for the reaction time. The preferred COD load ranges from $10-80 \mathrm{~kg} \cdot \mathrm{m}^{-3}$.

One of the biggest advantages related to the WO process is that decontamination is obtained with low polluting output gases, composed mainly of $\mathrm{CO}_{2}$, water steam, and oxygen, without hazardous by-products and low organic content in the final residue [8,11,12]. In addition, the WO effluent can be conveniently treated in a conventional wastewater treatment plant because of its high biodegradability, and, in some cases, it could also be used as a carbon source for the denitrification process, and as a substrate for the production of biopolymers [12]. Moreover, other researchers have also demonstrated that WO effluent represents an interesting energy vector; in fact, if it is treated by anaerobic digestion, biogas can be produced, and electric and thermal energy could be recovered [13].

Today, about 200 plants are in operation around the world (two of them in Italy), mostly to treat waste streams from petrochemical, chemical, and pharmaceutical industries, as well as residual sludge from urban wastewater treatment [12]. Detailed reviews about the WO process and its application are reported in Debellefontaine and Foussard [8], and Bhargava et al. [14].

According to Italian regulations [15], the soil and stones not containing dangerous substances (classified using the European Waste Code 170504 [16]) can be recovered, in simplified procedure, for the following uses: ceramic and brick manufacturing processes, environmental recovery, road embankments, and foundations. With the exception of the first recovery route, the release of pollutants (by means of a leaching test provided for UNI EN 1247-2 [17]) must be lower than the limit values reported in the regulations. According to Italian regulations, the simplified procedure (where no actual permission is necessary, only the notification of competent local authorities) is provided for a limited class of recovery operations that are completely defined by the law, both in terms of qualitative description, and the threshold quantities to be handled.

These residues could also be recovered by an ordinary procedure for further applications. The conventional use of fine particles falls mainly in the civil construction field, employed for the following uses: in the production of bitumen-based binder [18]; as unbound aggregate (usually mixed with lime) in road bases and subbases [19-21]; in the production of cement and concrete [22-25] and bricks $[26,27]$. These kinds of recovery could be limited due to the uncertainty regarding the physical properties of residues, and the effects on the products obtained.

The objective of this work was to carry out a detailed investigation of the WO technology as a treatment option for the decontamination of fine-grained soil, and to demonstrate that the remediation of the soil is achievable. To this end, two samples of fine soil, spiked with contaminants based on petroleum hydrocarbons, were subjected to the WO treatment. The first sample was contaminated with motor oil, while the second one was contaminated with a mix of motor oil and diesel only. 
This work is original. In fact, few studies have been reported that deal with the chemical oxidation process for the treatment of wastewater originating from the soil washing process [28-30], or with hot water extraction combined with in situ wet oxidation for the removal of polycyclic aromatic hydrocarbons (PAHs) from soil [31,32]. To our knowledge, no research dealing solely with the direct application of the WO process for the remediation of contaminated soils has been published.

\section{Materials and Methods}

\subsection{Soil Characteristics}

For the tests, two samples of fine soil (about $90 \%$ of soil passes through an ASTM (American Society for Testing and Materials) 200 mesh sieve) were spiked with the following: motor oil (soil \#1) and motor oil + diesel (soil \#2).

The contamination with motor oil was carried out using a heavy-duty synthetic engine oil designed for the lubrication of diesel engines (15W-40 type), while the other contamination was achieved using a commercial diesel fuel.

The artificial contamination was carried out by spiking the contaminants on $5 \mathrm{~kg}$ of samples. Specifically, the soil samples were put into two different vessels, after which the contaminants were spread on the soils (by means of a spray equipment). The soils were also mixed with trowels. Two days of aging (in a covered basin) were also provided for.

The main characteristics of the soil samples (before and after the artificial contamination) are summarized in Table 1.

The soils, from the granulometric point of view, are similar to the fine fraction of residues derived from mining activities. About $90 \%$ of the soil tested is silt and clay.

Table 1. Characteristics of the soils treated by wet oxidation.

\begin{tabular}{|c|c|c|c|c|c|}
\hline \multirow{2}{*}{ Parameter } & \multirow{2}{*}{ Measurement Unit } & \multicolumn{2}{|c|}{ Soil \#1 } & \multicolumn{2}{|r|}{ Soil \#2 } \\
\hline & & As Raw & Motor Oil & As Raw & Motor Oil + Diesel \\
\hline \multicolumn{6}{|l|}{ Contaminating medium } \\
\hline $\begin{array}{l}\text { Total Petroleum } \\
\text { Hydrocarbons (TPHs) }\end{array}$ & $\mathrm{mg} \cdot \mathrm{kg}_{\mathrm{dw}}-1$ & $<20$ & $1455 \pm 220$ & $<20$ & $4736 \pm 600$ \\
\hline $\begin{array}{l}\text { Total Polycyclic Aromatic } \\
\text { Hydrocarbons (PAHs) }\end{array}$ & $\mathrm{mg} \cdot \mathrm{kg}_{\mathrm{dw}}-1$ & $<0.1$ & $0.12 \pm 0.10$ & $<0.1$ & $0.20 \pm 0.05$ \\
\hline $\mathrm{pH}$ & - & n.a. & 8.0 & n.a. & 7.7 \\
\hline \multicolumn{6}{|l|}{ Granulometric fractions } \\
\hline Sand & $\%$ & n.a. & 11 & n.a. & 10 \\
\hline Silt & $\%$ & n.a. & 75 & n.a. & 76 \\
\hline Clay & $\%$ & n.a. & 14 & n.a. & 14 \\
\hline
\end{tabular}

dw: dry weight; n.a.: not available.

\subsection{WO Pilot Plant Characteristics}

Lab-scale WO tests were carried out in a continuously stirred autoclave operated in batch mode. The reactor (volume $=1.95 \mathrm{~L}$ realized in Hastelloy C-276) is equipped with an electric heating jacket and a water-cooling system in order to control the reaction temperature (maximum tolerable temperature $=350{ }^{\circ} \mathrm{C}$ ). The uniformity of the reaction is guaranteed by an internal mechanical stirrer. Pure oxygen is fed into the reactor by means of a supply system located on the top of the reactor's cover, where a manometer is installed for pressure control (maximum tolerable pressure $=20,265 \mathrm{kPa}$ ). A programmable logic controller (PLC) allows the control of the temperature during the tests (Figure 1). 


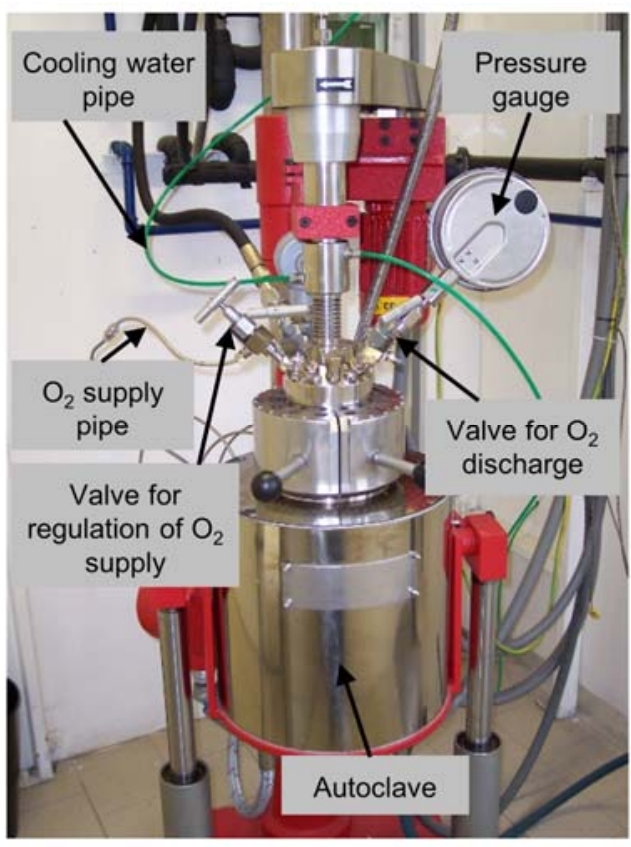

(a)

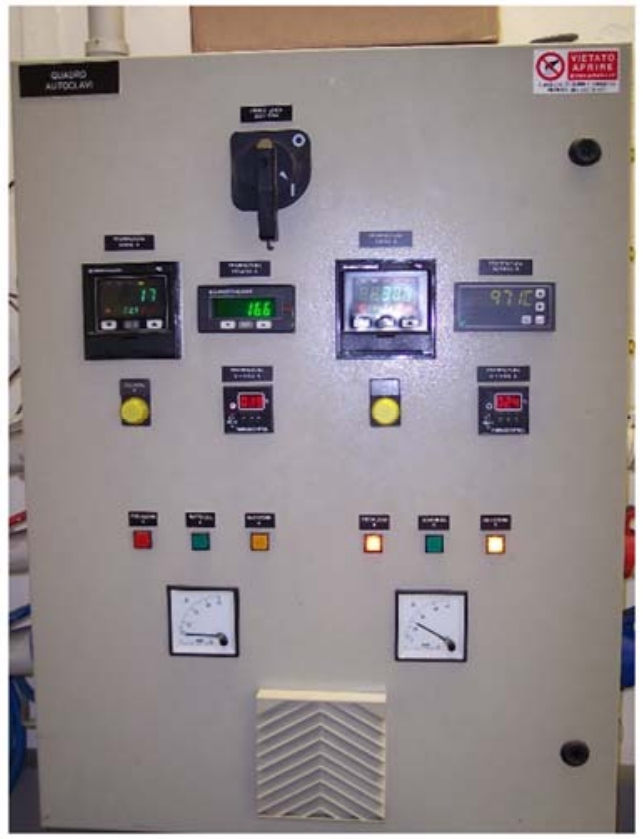

(b)

Figure 1. Wet oxidation reactor at lab-scale (a) and programmable logic controller (PLC) (b).

\subsection{Experimental Procedure}

The wet oxidation process can only be conducted on liquid matrices, so soil samples (soil \#1 and soil \#2) were diluted with tap water in order to obtain a suspension with a dry content of about $8 \%$. Before beginning the WO tests, total suspended solids (TSS) and COD were detected in the suspensions (this parameter is important because the stoichiometric amount of oxygen to be fed into the reactor is calculated in accordance with the ideal gas law, and COD's suspension value). In order to prevent any corrosion phenomena of the reactor ( $\mathrm{pH}$ drops during the tests), the solution's $\mathrm{pH}$ was adjusted to 13 by means of a concentrated solution of sodium hydroxide ( $0.1 \mathrm{M}$, Sigma-Aldrich, Milano, Italy).

For each test, $500 \mathrm{~mL}$ of the suspension was poured into the autoclave, and a pre-fixed amount of oxygen was fed into the reactor. Since oxygen can be a limiting factor for the kinetics of the WO process, all of the tests were conducted in over-stoichiometric conditions (1520 kPa and $2027 \mathrm{kPa}$ for soil \#1 and soil \#2, respectively). By means of the PLC, the temperature was held constant during the experiment. At the end of the tests, oxidized samples were cooled down to the ambient temperature, and a gaseous phase was extracted from the reactor. Samples of oxidized suspensions were collected and analyzed. $\mathrm{pH}, \mathrm{TSS}$ and heavy metals analyses were performed according to APHA, AWWA, and WEF standard methods [33], TPHs according to the USEPA 8015D2003 method [34], and polycyclic aromatic hydrocarbons (PAHs) according to the APAT-IRSA-CNR 25Q64 method [35].

For both of the soil solutions, seven oxidation tests were performed one by one at varying temperatures $\left(200,250\right.$, and $300{ }^{\circ} \mathrm{C}$ ) and reaction times $(30-120 \mathrm{~min}$, with steps of $30 \mathrm{~min}$ ); the experimental program is reported in Table 2. For each set of operating conditions, one wet oxidation test was performed.

The choice of the experimental conditions was based on the operating conditions usually adopted by the manager of an Italian full scale wet oxidation plant.

In order to evaluate the recovery options, a chemical characterization was performed on the solid residues generated by the wet oxidation test that provides the best performance (for soil \#1) in terms of the removal of TPHs. In addition, the single stage leaching test was carried out. 
The single stage leaching test was performed in water for $24 \mathrm{~h}$ according to UNI 12457-2 [17]. The sample was kept in contact with demineralized water (liquid to solid ratio (L/S) equal to $10 \mathrm{~L} \cdot \mathrm{kg}^{-1}$ ) for $24 \mathrm{~h}$ under stirring conditions (by means of an overhead mixer).

The chemical analysis of the leachate was carried out according to APHA, AWWA and WEF standard methods [33].

Table 2. Wet oxidation tests performed on the two samples of soils.

\begin{tabular}{|c|c|c|c|c|}
\hline Soil & Test & $\begin{array}{l}\text { Temperature } \\
\left({ }^{\circ} \mathrm{C}\right)\end{array}$ & $\begin{array}{l}\text { Initial Partial Pressure of Pure Oxygen } \\
(\mathbf{k P a})\end{array}$ & $\begin{array}{l}\text { Reaction Time } \\
\text { (min) }\end{array}$ \\
\hline \multirow{7}{*}{ Soil \#1 } & A. 1 & 200 & \multirow{3}{*}{1520} & \multirow{3}{*}{30} \\
\hline & A. 2 & 250 & & \\
\hline & A. 3 & 300 & & \\
\hline & A. 4 & \multirow{4}{*}{250} & \multirow{4}{*}{1520} & 30 \\
\hline & A. 5 & & & 60 \\
\hline & A. 6 & & & 90 \\
\hline & A. 7 & & & 120 \\
\hline \multirow{7}{*}{ Soil \#2 } & B.1 & 200 & \multirow{3}{*}{2027} & \multirow{3}{*}{30} \\
\hline & B. 2 & 250 & & \\
\hline & B. 3 & 300 & & \\
\hline & B.4 & \multirow{4}{*}{250} & \multirow{4}{*}{2027} & 30 \\
\hline & B. 5 & & & 60 \\
\hline & B.6 & & & 90 \\
\hline & B.7 & & & 120 \\
\hline
\end{tabular}

\section{Results and Discussion}

\subsection{Results of WO Tests}

The results of the WO tests performed on soils \#1 and \#2 are reported in Figures 2 and 3, respectively. Both figures show with a dashed line the threshold $\left(750 \mathrm{mg}(\mathrm{TPHs}) \cdot \mathrm{kg}_{\mathrm{dw}}{ }^{-1}\right)$ set by Italian law [36] for reusing the treated soil in commercial and industrial sites. It is important to observe that, in regards to the soil protection, there are no complete and coherent rules within the European Union (E.U.); only a few E.U. member states have specific legislation. There are, for instance, directives aimed at agriculture, water, and waste management, however they have a different kind of purpose, and are not sufficient to ensure an adequate protection level for all soils in Europe. For example, the comparative analysis among various environmental legislations regarding the contamination of soil with oil products in some European countries (Latvia, Estonia, Lithuania, Finland, Denmark, Norway, Italy, The Netherlands) [37], highlighted that the most precautionary limit is adopted by Latvia $\left(1 \mathrm{mg} \cdot \mathrm{kg}^{-1}\right)$, while the highest target values are adopted by Finland $\left(100-600 \mathrm{mg} \cdot \mathrm{kg}^{-1}\right)$. A few countries use two limit values as a function of the use of the soil after remediation (Italy), while others countries even use three limits (Latvia and Estonia). 


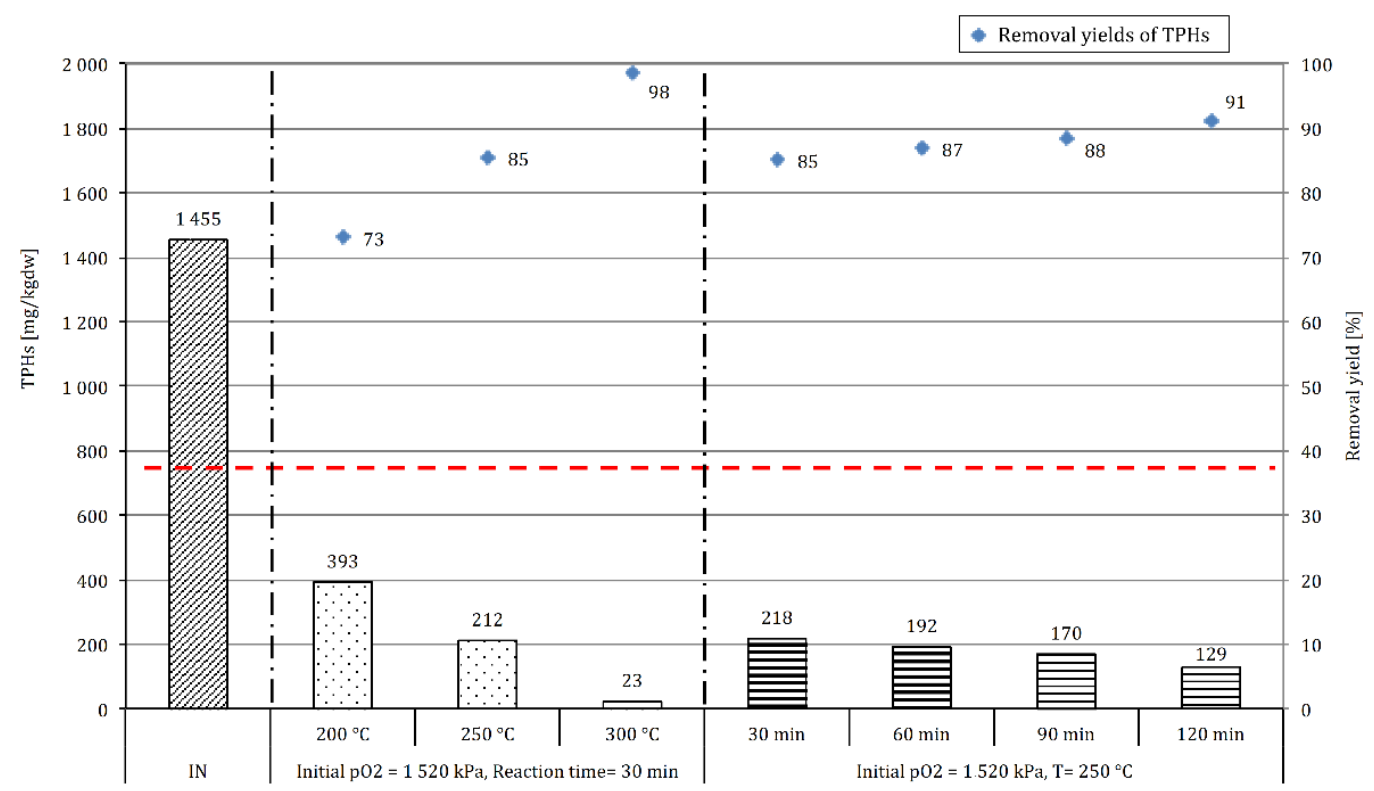

Figure 2. Results obtained for soil \#1. Initial $\mathrm{pO}_{2}$ = initial partial pressure of oxygen fed into the reactor. Dotted line represents the limit $\left(750 \mathrm{mg}(\mathrm{TPHs}) \cdot \mathrm{kg}_{\mathrm{dw}}{ }^{-1}\right)$ imposed by Italian law for the reuse of the treated soil [36]. TPHs: total petroleum hydrocarbons.

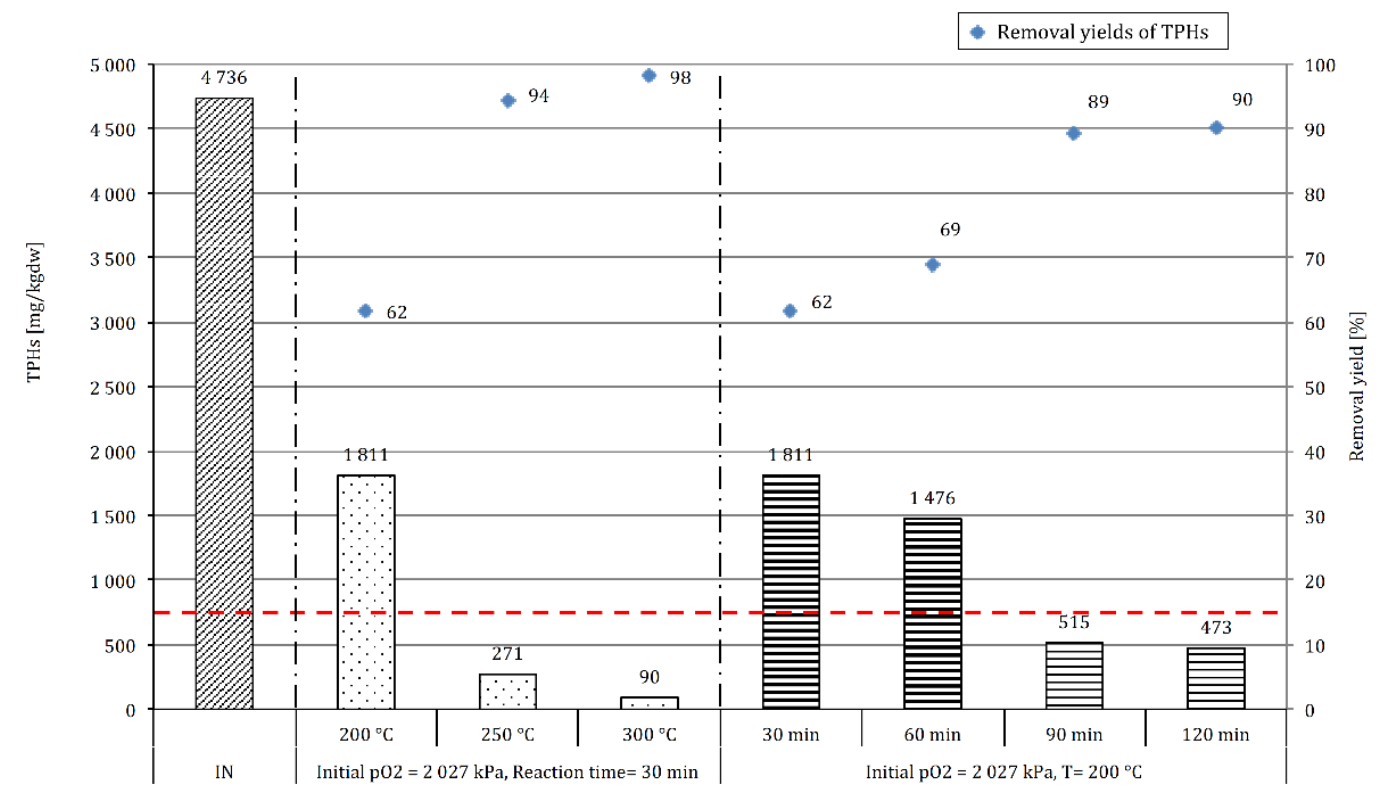

Figure 3. Results obtained for soil \#2. Initial $\mathrm{pO}_{2}=$ initial partial pressure of oxygen fed into the reactor. Dotted line represents the limit $\left(750 \mathrm{mg}(\mathrm{TPHs}) \cdot \mathrm{kg}_{\mathrm{dw}}{ }^{-1}\right)$ imposed by Italian law for the reuse of the treated soil [36].

\subsubsection{Effect of Temperature}

As expected, by increasing the reaction temperature (while keeping the reaction time constant at 30 minutes) the amount of hydrocarbons in the soil decreases (the higher the temperature, the higher the removal of TPHs). In both soils, at the highest temperature $\left(300^{\circ} \mathrm{C}\right)$ the residual amount of TPHs is substantially negligible (23 and $90 \mathrm{mg} \cdot \mathrm{kg}_{\mathrm{dw}}{ }^{-1}$ for soil \#1 and \#2, respectively), with removal yields close to $100 \%$. 
In both cases, the higher increase in the TPHs removal yield was recorded as passing from $200-250{ }^{\circ} \mathrm{C}$, especially for soil \#2, where the removal yield increased by about 30\%, reaching, substantially, a plateau (this is demonstrated by the fact that in the test conducted at $300{ }^{\circ} \mathrm{C}$, the removal yield only increased by $4 \%$ ). These results are in agreement with the findings of reference [38], where a similar matrix (fine grains derived from a soil washing pilot plant) was tested.

From the results, it can be seen that independent of the kind of contamination (motor oil or a mix of motor oil and diesel), $250{ }^{\circ} \mathrm{C}$ represents the temperature at which the normative constraint of $750 \mathrm{mg}(\mathrm{TPHs}) \cdot \mathrm{kg}_{\mathrm{dw}^{-1}}{ }^{-1}$ can be reached.

In addition, at temperatures equal to or higher than $250{ }^{\circ} \mathrm{C}$, in both soils the PAHs content was lower than the detection threshold foreseen by the analytical method $\left(<0.01 \mathrm{mg} \cdot \mathrm{kg}_{\mathrm{dw}}{ }^{-1}\right)$, revealing that the WO process is also effective on this class of compounds. The reduction of the PAHs content in the soil is an important goal, as these compounds are dangerous for human health (cancer is a primary human health risk of exposure to PAHs, as reported by Bostrom et al. [39]).

\subsubsection{Effect of Reaction Time}

These tests were performed at two different temperatures $\left(250\right.$ and $200{ }^{\circ} \mathrm{C}$ for soil $\# 1$ and $\# 2$, respectively) in order to better investigate the effect of reaction time.

Operating with a severe temperature (tests performed on soil $\# 1$ at $250^{\circ} \mathrm{C}$ ), the increase in the reaction time definitely allows the reduction of the content of TPHs, even if the removal yield $(\eta)$ only increases by $6 \%$ passing from $30(\eta=85 \%)$ to $120 \mathrm{~min}(\eta=91 \%)$. This shows that, under those conditions, the oxidation process, substantially, reaches a plateau. Therefore, it is not convenient to use reaction times greater than 30 minutes, as the legislative constraints are already complied using this reaction time, and the additional environmental benefits obtained with higher reaction times are almost negligible.

By contrast, at a temperature of $200{ }^{\circ} \mathrm{C}$ (tests on soil \#2), the removal of TPHs is more influenced by the reaction time. In fact, passing from 30-90 $\mathrm{min}$, the amount of TPHs in the soil decreases by a further $27 \%$, complying with the legislative limit of $750 \mathrm{mg}(\mathrm{TPHs}) \cdot \mathrm{kg}_{\mathrm{dw}}{ }^{-1}$. No significant improvements in the TPHs reduction were obtained by extending the reaction time to $120 \mathrm{~min}$.

These results also show that for hydrocarbons, up to a given point, the conversion of organic substances does not increase (reaching a plateau) even if reaction time and temperature are increased. In the scientific literature, similar results are reported for sewage sludge [12,40], or wastes from chemical industries [8].

From an operating point of view, it is also important to evaluate the value of $\mathrm{pH}$ obtained after the treatment, mainly because (1) effluent with low/high $\mathrm{pH}$ cannot be treated directly in a biological process, and (2) corrosion effects can reduce the service life of the plant (at low values of $\mathrm{pH}$ ). The $\mathrm{pH}$ at the end of the reaction depends substantially on the kind of substance subjected to WO; therefore, the $\mathrm{pH}$ control is an important issue.

Figure 4 shows the relation between the $\mathrm{pH}$ of the solution and the reaction time. It can be observed that (1) the higher the content of contaminant in the soil (soil \#2) the lower the final value of $\mathrm{pH}(6.8)$, and (2) by increasing the reaction time, the $\mathrm{pH}$ slightly decreases. This occurs due to the fact that during the WO process, the organic substance is converted into volatile fatty acids (VFAs), therefore the higher the amount of TPHs removed, the higher the amount of VFAs produced (and, consequently, the lower the $\mathrm{pH}$ of the solution); more details can be found in Debellefontaine and Foussard [8].

Finally, it seems that the final value of $\mathrm{pH}$ is affected by the amount of TPHs removed, rather than by the kind of contaminant. 


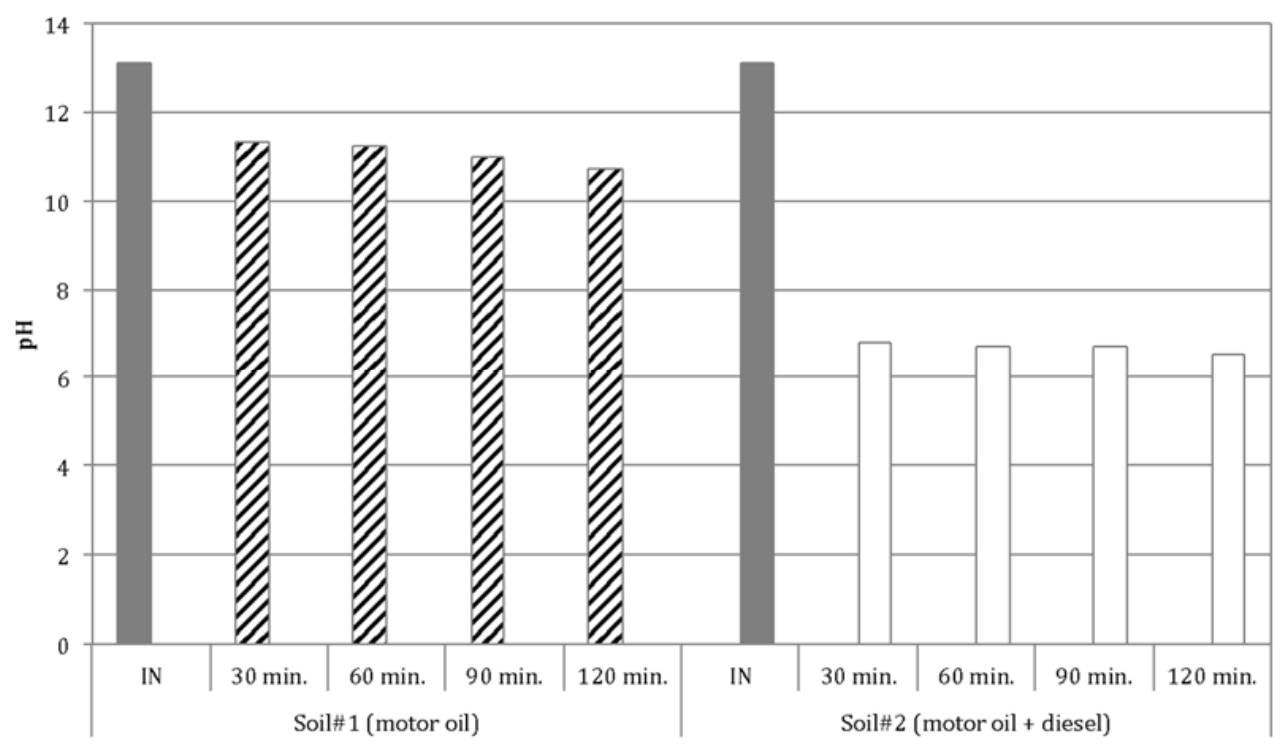

Figure 4. Soils' $\mathrm{pH}$ values after the wet oxidation (WO) treatment.

\subsubsection{COD Mass Balance}

As concerns soil \# 1, the COD removal yields varied from 38-78\%. The results obtained by the mass balance (Figure 5) show that, despite the increase of temperature allows the attainment of high COD reduction (at $300{ }^{\circ} \mathrm{C}$, the COD removal yield is $78 \%$ ), only the increase in contact time lead to a lower content of COD in the solid fraction (at a temperature of $250{ }^{\circ} \mathrm{C}$, a contact time of 120 minutes involves COD in solid equal to $2 \%$ of the initial total COD).

Therefore, the extraction of pollutants from the solid fraction could be the limiting factor for the entire remediation rate. Some authors [31,32] have investigated the extraction of PAHs (i.e., with hot water) and the subsequent wet oxidation. Moreover, Thomsen and Laturnus [41] showed that the application of an alkaline extraction prior to the wet oxidation could increase the degradation efficiency of organic pollutants.

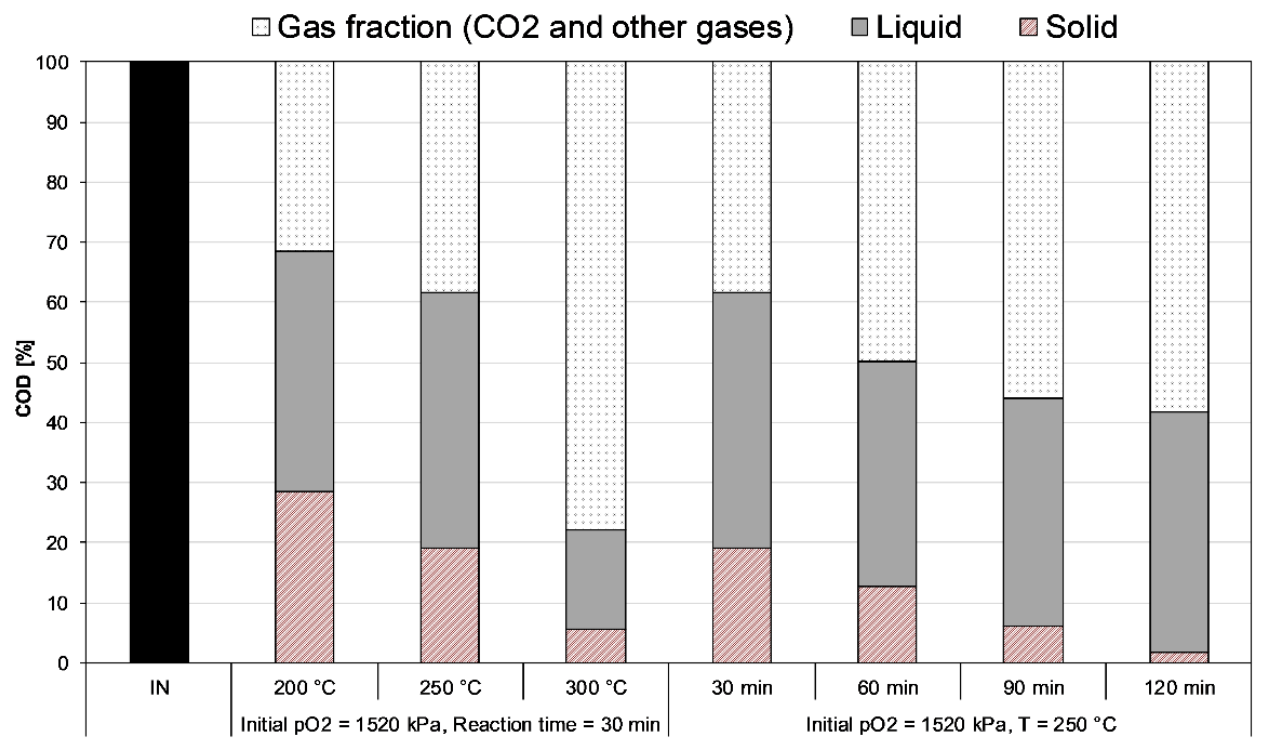

Figure 5. Results obtained for soil \#1. COD balance after the WO treatment. 


\subsection{Evaluation of WO Solid Residue Recovery Options}

The contents of pollutants measured in soil \#1 before and after the WO process (under the best oxidation conditions in terms of the highest removal of TPHs) are reported in Table 3. It can be noted that the solid residue resulting from WO treatment can be recovered in sites for commercial and industrial use (as reported in Legislative Decree n. 152/2006, and further modification).

As concerns nickel, although additional investigations were not carried out, the increase in concentration of the solid residue after WO could be due to the possible release of nickel from the reactor during the WO tests. In fact, nickel is the main component of the reactor alloy (i.e., Hastelloy C-276).

Table 3. Contents of pollutants in soil \#1 before and after WO.

\begin{tabular}{|c|c|c|c|c|}
\hline \multirow[b]{2}{*}{ Parameter } & \multicolumn{2}{|c|}{ Concentration $\left(\mathrm{mg} \cdot \mathrm{kg}_{\mathrm{dw}}{ }^{-1}\right)$} & \multicolumn{2}{|c|}{ Limit Value Legislative Decree $\mathrm{n} .152(2006)\left(\mathrm{mg} \cdot \mathrm{kg}_{\mathrm{dw}}{ }^{-1}\right)$} \\
\hline & IN & OUT * & $\begin{array}{l}\text { Public, Private and } \\
\text { Residential Use (A) }\end{array}$ & $\begin{array}{l}\text { Commercial and } \\
\text { Industrial Use (B) }\end{array}$ \\
\hline $\mathrm{Cu}$ & $54 \pm 8$ & $51 \pm 8$ & 120 & 600 \\
\hline $\mathrm{Zn}$ & $131 \pm 16$ & $137 \pm 16$ & 150 & 1500 \\
\hline $\mathrm{Be}$ & $2.8 \pm 0.5$ & $2.3 \pm 0.4$ & 2 & 10 \\
\hline Co. & $37.6 \pm 5$ & $35.1 \pm 5$ & 20 & 250 \\
\hline $\mathrm{Ni}$ & $198 \pm 27$ & $239 \pm 35$ & 120 & 500 \\
\hline $\mathrm{V}$ & $78.5 \pm 10$ & $56.2 \pm 7$ & 90 & 250 \\
\hline As & $31.6 \pm 5$ & $18.0 \pm 3$ & 20 & 50 \\
\hline $\mathrm{Cd}$ & $0.4 \pm 0.06$ & $0.3 \pm 0.05$ & 2 & 15 \\
\hline $\mathrm{Cr}_{\mathrm{TOT}}$ & $131 \pm 18$ & $110 \pm 15$ & 150 & 800 \\
\hline $\mathrm{Pb}$ & $31 \pm 4$ & $29 \pm 4$ & 100 & 1000 \\
\hline Se & $3.4 \pm 0.5$ & $3.3 \pm 0.5$ & 3 & 15 \\
\hline $\mathrm{Hg}$ & $<0.1$ & $<0.1$ & 1 & 5 \\
\hline $\mathrm{Sb}$ & $1 \pm 0.14$ & $<1$ & 10 & 30 \\
\hline TPHs & $1455 \pm 220$ & $23 \pm 7$ & 50 & 750 \\
\hline PAHs & $0.12 \pm 0.1$ & $<1$ & 1 & 100 \\
\hline
\end{tabular}

${ }^{*} \mathrm{~T}: 300{ }^{\circ} \mathrm{C}$, reaction time: $30 \mathrm{~min}$, initial $\mathrm{pO}_{2}: 1520 \mathrm{kPa}$. The bold values do not respect the limit values for public, private, and residential use (A), but are lower than limit values for commercial and industrial use (B).

The results of the leaching test (according to UNI EN 12457-2) on the solid fraction obtained by the WO on soil \#1 (under the oxidation conditions that enable the highest removal of TPHs) are reported in Table 4.

The release of nickel, total chromium, arsenic, and COD is higher than limit values for waste recovery in simplified procedure (according to Ministerial Decree n. 186/2006 [15]); this behavior is due to the high $\mathrm{pH}$ measured in the leachate (10.1). In fact, as reported by Jang et al. [42], the arsenic and the total chromium showed strong $\mathrm{pH}$ dependence of leaching. The releases are higher in acidic and alkaline conditions with respect to the values obtained for neutral $\mathrm{pH}$. Similar behavior is observed for nickel [43]. Moreover, as concerns the COD, as reported by Andersson et al. [44], the increase of pH involves an enhancement in dissolved organic carbon release.

Although some pollutants are higher than the limit values set out by Ministerial Decree n. 186/2006, these residues could be recovered, in simplified procedure, for ceramic and brick manufacturing processes. 
Table 4. Results of leaching test (UNI EN 12457-2) on solid residue from WO (soil \#1-T: $300{ }^{\circ} \mathrm{C}$, reaction time: $30 \mathrm{~min}$, initial $\left.\mathrm{pO}_{2}: 1520 \mathrm{kPa}\right)$.

\begin{tabular}{ccc}
\hline Parameter & $\begin{array}{c}\text { Concentration } \\
\left(\mathbf{m g} \cdot \mathbf{L}^{-\mathbf{1}}\right)\end{array}$ & $\begin{array}{c}\text { Limit Values Ministerial Decree } \mathbf{n . ~ 1 8 6}(\mathbf{2 0 0 6}) \\
\left(\mathbf{m g} \cdot \mathbf{L}^{-\mathbf{1}}\right)\end{array}$ \\
\hline $\mathrm{NO}_{3}{ }^{-}$ & $<1$ & 50 \\
$\mathrm{~F}^{-}$ & $<0.2$ & 1.5 \\
$\mathrm{SO}_{4}{ }^{-}$ & $7 \pm 1$ & 250 \\
$\mathrm{Cl}^{-}$ & $2 \pm 0.4$ & 100 \\
$\mathrm{CN}^{-}$ & $<0.005$ & 0.05 \\
$\mathrm{Ba}$ & $<0.1$ & 1 \\
$\mathrm{Cu}$ & $<0.05$ & 0.05 \\
$\mathrm{Zn}$ & $<0.1$ & 3 \\
$\mathrm{Be}$ & $<0.001$ & 0.01 \\
$\mathrm{Co}$. & $0.014 \pm 0.04$ & 0.25 \\
$\mathrm{Ni}$ & $\mathbf{0 . 1 0 5} \pm \mathbf{0 . 0 3}$ & 0.01 \\
$\mathrm{~V}$ & $0.16 \pm 0.04$ & 0.25 \\
$\mathrm{As}$ & $\mathbf{0 . 1} \pm \mathbf{0 . 0 4}$ & 0.05 \\
$\mathrm{Cd}$ & $<0.0005$ & 0.005 \\
$\mathrm{Cr}$ & 0.05 \\
$\mathrm{~Pb}$ & $0.013 \pm 0.004$ & 0.05 \\
$\mathrm{Se}$ & $<0.005$ & 0.01 \\
$\mathrm{Hg}$ & $<0.0005$ & 0.001 \\
$\mathrm{COD}$ & $\mathbf{1 1 1} \pm \mathbf{2 0}$ & 30 \\
$\mathrm{pH}$ & 10.1 & $5.5 \div 12$ \\
\hline
\end{tabular}

The bold values do not respect the normative limits for waste reuse in simplified procedure.

\section{Conclusions}

In this study, two samples of soil spiked with contaminants containing hydrocarbons were treated by the WO process. The soil was characterized by a high content of fine fraction, and different hydrocarbon contamination, both in terms of the kind of contaminants (motor oil and motor oil + diesel), and the concentrations.

The results obtained show that both the temperature and the reaction time influence the removal of TPHs. In fact, the lowest removal yields were obtained at the lowest temperature $\left(200{ }^{\circ} \mathrm{C}\right)$ and reaction time (30 min). Generally, $30 \mathrm{~min}$ treatment at $250{ }^{\circ} \mathrm{C}$ is enough to respect the limit imposed by Italian law for the reuse of the treated soil; in those conditions, in fact, the TPHs removal rates are close to $95 \%$. Moreover, at those conditions, negligible concentrations of PAHs are obtained after the treatment. Similar results can be reached at $200{ }^{\circ} \mathrm{C}$, with $90 \mathrm{~min}$ of treatment.

As concerns the characterization of the solid residue obtained from WO treatment, with the aim of assessing recovery options, the results of chemical analysis and the leaching test suggest that these residues could be recovered for ceramic and brick manufacturing processes.

In conclusion, this study demonstrates that WO represents an effective process for the remediation of fine soils contaminated with TPHs and PAHs.

Author Contributions: M.C.C. and M. V. have designed the work and supervised the research activities. M.C. carried out data analysis and the manuscript drafting. A.A. and S.S. have edited the section concerning the evaluation of recovery options for the solid residues.

Acknowledgments: The authors are grateful to 3V Green Eagle, which supported the experimental activity within the official collaboration with the University of Pavia on the research "Advanced processes aimed to treat liquid waste and sludge". The authors also wish to thank Eng. Sabrina Zanaboni, who performed the wet oxidation tests.

Conflicts of Interest: The authors declare no conflicts of interest. 


\section{References}

1. Pavel, L.V.; Gavrilescu, M. Overview of ex situ decontamination techniques for soil cleanup. Environ. Eng. Manag. J. 2008, 7, 815-834.

2. Collivignarelli, M.C.; Pedrazzani, R.; Sorlini, S.; Abbà, A.; Bertanza, G. $\mathrm{H}_{2} \mathrm{O}_{2}$ Based Oxidation Processes for the Treatment of Real High Strength Aqueous Wastes. Sustainability 2017, 9, 244. [CrossRef]

3. Huling, S.G.; Pivetz, B.E. In-Situ Chemical Oxidation; Publication EPA/600/R-06/072; U.S. EPA: Washington, DC, USA, 2006; pp. 1-58.

4. Semple, K.T.; Morriss, A.W.J.; Paton, G.I. Bioavailability of hydrophobic organic contaminants in soils: Fundamental concepts and techniques for analysis. Eur. J. Soil Sci. 2003, 54, 809-818. [CrossRef]

5. Dermont, G.; Bergeron, M.; Mercier, M.; Richer-Laflèche, M. Soil washing for metal removal: A review of physical/chemical technologies and field applications. J. Hazard. Mater. 2008, 152, 1-31. [CrossRef] [PubMed]

6. Komìnkovà, D.; Fabbricino, M.; Gurung, B.; Race, M.; Tritto, C.; Ponzo, A. Sequential application of soil washing and phytoremediation in the land of fires. J. Environ. Manag. 2018, 206, 1081-1089. [CrossRef]

7. European Commission. Closing the Loop-An EU Action Plan for the Circular Economy. Communication from the Commission to the European Parliament, the Council, the European Economic and Social Committee and the Committee of the Regions, COM/2015/0614 Final. Available online: http:/ / eur-lex.europa.eu/lega 1-content/EN/TXT/?uri=CELEX:52015DC0614 (accessed on 23 January 2018).

8. Debellefontaine, H.; Foussard, J.N. Wet Air Oxidation for the treatment of industrial wastes. Chemical aspects, reactor design and industrial application in Europe. Waste Manag. 2000, 20, 15-25. [CrossRef]

9. Ramos, J.B.E.; Miguélez, J.R.P. Technical viability of the wet oxidation process (WAO) for the treatment of percolates from landfills: A case study. Acad. J. Sci. Res. 2017, 5, 726-731. [CrossRef]

10. Suàrez-Iglesias, O.; Urrea, J.L.; Oulego, P.; Collado, S.; Dìaz, M. Valuable compounds from sewage sludge by thermal hydrolysis and wet oxidation. Sci. Total Environ. 2017, 584-585, 921-934. [CrossRef] [PubMed]

11. Genç, N.; Yonsel, S.; Dağaşn, L.; Nur Onar, A. Wet oxidation: A pre-treatment for sludge. Waste Manag. 2002, 22, 611-616. [CrossRef]

12. Slavik, E.; Galessi, R.; Rapisardi, A.; Salvetti, R.; Bonzagni, P.; Bertanza, G.; Menoni, L.; Orhone, D.; Sözen, S. Wet Oxidation as an advanced and sustainable technology for sludge treatment and management: Results from research activities and industrial-scale experiences. Dry. Technol. 2015, 33, 1309-1317. [CrossRef]

13. Bertanza, G.; Galessi, R.; Menoni, L.; Pedrazzani, R.; Salvetti, R.; Zanaboni, S. Anaerobic treatability of liquid residue from wet oxidation of sewage sludge. Environ. Sci. Pollut. Res. 2015, 22, 7317-7326. [CrossRef] [PubMed]

14. Bhargava, S.K.; Tardio, J.; Prasad, J.; Föger, K.; Akolekar, D.B.; Grocott, S.C. Wet Oxidation and Catalytic Wet Oxidation. Ind. Eng. Chem. Res. 2006, 45, 1221-1258. [CrossRef]

15. Istituto Poligrafico e Zecca dello Stato. Ministerial Decree n. 186 Dated 5 April 2006. Regulatory That Modified Ministerial Decree Dated 5 February 1998. Official Gazette n. 115, 19 May 2006. Available online: http:/ / www.gazzettaufficiale.it/atto/serie_generale/caricaDettaglioAtto/originario?atto.d ataPubblicazioneGazzetta=2006-05-19\&atto.codiceRedazionale=006G0202\&elenco30giorni=false (accessed on 16 May 2018).

16. European Commission. Commission Decision of 18 December 2014 amending Decision 2000/532/EC on the list of waste pursuant to Directive 2008/98/EC of the European Parliament and of the Council. Official Journal of the European Union. 2014. Available online: https:/ / eur-lex.europa.eu/legal-content/EN/TXT/? uri=celex:32014D0955 (accessed on 16 May 2018).

17. UNI (Ente Italiano di Normazione). UNI EN 12457-2. Characterisation of Waste-Leaching-Compliance Test for Leaching of Granular Waste Materials and Sludges-Part 2: One Stage Batch Test at a Liquid to Solid Ratio of $10 \mathrm{~L} / \mathrm{kg}$ for Materials with Particle Size below $4 \mathrm{~mm}$ (without or with Size Reduction). 2004. Available online: http:/ / store.uni.com/catalogo/index.php/uni-en-12457-2-2004.html (accessed on 16 May 2018).

18. Hill, A.R.; Dawson, A.R.; Mundy, M. Utilisation of aggregate materials in road construction and bulk fill. Resour. Conserv. Recycl. 2001, 32, 305-320. [CrossRef]

19. De Rezende, L.R.; De Carvalho, J.C. The use of quarry waste in pavement construction. Resour. Conserv. Recycl. 2003, 39, 91-105. [CrossRef] 
20. Hassan, H.F.; Taha, R.; Al Rawas, A.; Al Shandoudi, B.; Al Gheithi, K.; Al Barami, A. Potential uses of petroleum-contaminated soil in highway construction. Constr. Build. Mater. 2005, 19, 646-652. [CrossRef]

21. Akbulut, H.; Gürer, C. Use of aggregates produced from marble quarry waste in asphalt pavements. Build. Environ. 2007, 42, 1921-1930. [CrossRef]

22. Topçu, I.B.; Uğurlu, A. Effect of the use of mineral filler on the properties of concrete. Cem. Concr. Res. 2003, 33, 1071-1075. [CrossRef]

23. Bouchard, L.; Lafthaj, Z.; Skoczylas, F. River sediments contaminated by heavy metals and organic compounds: Characterization, treatment and valorization. In Proceedings of the International RILEM Conference on the Use of Recycled Materials in Buildings and Structures, Barcelona, Spain, 8-11 November 2004; Vàzquez, E., Hendriks, C.F., Janssen, G.M.T., Eds.; RILEM Publications S.A.R.L.: Bagneux, France, 2004; pp. 807-813.

24. Navia, R.; Rivela, B.; Lorber, K.E.; Méndez, R. Recycling contaminated soil as alternative raw material in cement facilities: Life cycle assessment. Resour. Conserv. Recycl. 2006, 48, 339-356. [CrossRef]

25. Sorlini, S.; Abbà, A.; Collivignarelli, C. Recovery of MSWI and soil washing residues as concrete aggregates. Waste Manag. 2011, 31, 289-297. [CrossRef] [PubMed]

26. Hamer, K.; Karius, V. Brick production with dredged harbour sediments. An industrial-scale experiment. Waste Manag. 2002, 22, 521-530. [CrossRef]

27. Mahzuz, H.M.A.; Alam, R.; Alam, M.N.; Basak, R.; Islam, M.S. Use of arsenic contaminated sludge in making ornamental bricks. Int. J. Environ. Sci. Technol. 2009, 6, 291-298.

28. Saxe, J.K.; Allen, H.E.; Nicol, G.R. Fenton Oxidation of Polycyclic Aromatic Hydrocarbons after Surfactant-Enhanced Soil Washing. Environ. Eng. Sci. 2000, 17, 233-244. [CrossRef]

29. Bandala, E.R.; Velasco, Y.; Torres, L.G. Decontamination of soil washing wastewater using solar driven advanced oxidation processes. J. Hazard. Mater. 2008, 160, 402-407. [CrossRef] [PubMed]

30. Villa, R.D.; Trovó, A.G.; Pupo Nogueira, R.F. Soil remediation using a coupled process: Soil washing with surfactant followed by photo-Fenton oxidation. J. Hazard. Mater. 2010, 174, 770-775. [CrossRef] [PubMed]

31. Dadkhah, A.A.; Akgerman, A. Hot water extraction with in situ wet oxidation: PAHs removal from soil. J. Hazard. Mater. 2002, 93, 307-320. [CrossRef]

32. Dadkhah, A.A.; Akgerman, A. Hot water extraction with in situ wet oxidation: Kinetics of PAHs removal from soil. J. Hazard. Mater. 2006, 137, 518-526. [CrossRef] [PubMed]

33. APHA; AWWA; WEF. Standard Methods for the Examination of Water and Wastewater, 22nd ed.; American Public Health Association: Washington, DC, USA, 2012; ISBN 978-087553-013-0.

34. U.S. EPA. Method 8015D: Nonhalogenated Organics Using Gas Chromatography/Flame Ionization Detection (GC/FID). Available online: https:/ /www.epa.gov/sites/production/files/2015-12/documents/8015d_r4. pdf (accessed on 23 January 2018).

35. APAT-IRSA-CNR. Analytical Methods for Water; APAT Handbooks and guidelines n. 29/2003; Istituto Grafico Editoriale Romano: Roma, Italy, 2003; ISBN 88-448-0083-7. Available online: http:/ / www.isprambiente.gov .it/it/pubblicazioni/manuali-e-linee-guida/metodi-analitici-per-le-acque (accessed on 16 May 2018).

36. Istituto Poligrafico e Zecca dello Stato. Legislative Decree n. 152 Dated 3 April 2006. Norms Concerning the Environment. Official Gazette n. 88, 14 April 2006; Ordinary Supplement n. 96. Available online: http:/ / www.gazzettaufficiale.it/atto/serie_generale/caricaDettaglioAtto/originario?atto.dataPub blicazioneGazzetta=2006-04-14\&atto.codiceRedazionale=006G0171 (accessed on 16 May 2018).

37. Paccassoni, F.; Kalnina, D.; Piga, L. Comparative studies of oil product regulation in polluted soil for several industrialized countries. IOP Conf. Ser. Mater. Sci. Eng. 2017, 251, 012066. [CrossRef]

38. Vaccari, M.; Collivignarelli, M.C.; Canato, M. Reuse of Hydrocarbon-Contaminated Sludge from Soil Washing Process: Issues and Perspectives. Chem. Eng. Trans. 2012, 28, 169-174. [CrossRef]

39. Bostrom, C.E.; Gerde, P.; Hanberg, A.; Jernstrom, B.; Johansson, C.; Kyrklund, T.; Rannug, A.; Tornqvist, M.; Victorin, K.; Westerholm, R. Cancer risk assessment, indicators, and guidelines for polycyclic aromatic hydrocarbons in the ambient air. Environ. Health Perspect. 2002, 110, 451-488. [CrossRef] [PubMed]

40. Luck, F. Wet air oxidation: Past, present and future. Catal. Today 1999, 53, 81-91. [CrossRef]

41. Thomsen, A.B.; Laturnus, F. The influence of different soil constituents on the reaction kinetics of wet oxidation of the creosote compound quinolone. J. Hazard. Mater. 2001, 81, 193-203. [CrossRef] 
42. Jang, Y.-C.; Townsend, T.G.; Ward, M.; Bitton, G. Leaching of Arsenic, Chromium, and Copper in a Contaminated Soil at a Wood Preserving Site. Bull. Environ. Contam. Toxicol. 2002, 69, 808-816. [CrossRef] [PubMed]

43. Dijkstra, J.; Meeussen, J.C.L.; Comans, R.N.J. Leaching of Heavy Metals from Contaminated Soils: An Experimental and Modeling Study. Environ. Sci. Technol. 2004, 38, 4390-4395. [CrossRef] [PubMed]

44. Andersson, S.; Nilsson, S.I.; Saetre, P. Leaching of dissolved organic carbon (DOC) and dissolved organic nitrogen (DON) in mor humus as affected by temperature and pH. Soil Biol. Biochem. 2000, 32, 1-10. [CrossRef]

(c) (C) 2018 by the authors. Licensee MDPI, Basel, Switzerland. This article is an open access article distributed under the terms and conditions of the Creative Commons Attribution (CC BY) license (http://creativecommons.org/licenses/by/4.0/). 